Article

\title{
Exploring the Impact of Multitemporal DEM Data on the Susceptibility Mapping of Landslides
}

\author{
Jiaying $\mathrm{Li}^{1,2,3}$, Weidong Wang ${ }^{1,2}$, Zheng Han ${ }^{1, *}$, Yange $\mathrm{Li}^{1}$ and Guangqi Chen ${ }^{3}$ \\ 1 School of Civil Engineering, Central South University, Changsha 410075, Hunan, China; \\ 184801058@csu.edu.cn (J.L.); 701139@csu.edu.cn (W.W.); liyange@csu.edu.cn (Y.L.) \\ 2 Key Laboratory of Heavy-haul Railway, Ministry of Education, Changsha 410075, Hunan, China \\ 3 Department of Civil and Structural Engineering, Kyushu University, Fukuoka 819-0395, Japan; \\ chen@civil.kyushu-u.ac.jp \\ * Correspondence: zheng_han@csu.edu.cn; Tel.: +86-18874163071
}

Received: 5 March 2020; Accepted: 2 April 2020; Published: 6 April 2020

Featured Application: Landslide susceptibility assessment and other geological disaster assessment issues.

\begin{abstract}
Digital elevation models (DEMs) are fundamental data models used for susceptibility assessment of landslides. Due to landscape change and reshaping processes, a DEM can show obvious temporal variation and has a significant influence on assessment results. To explore the impact of DEM temporal variation on hazard susceptibility, the southern area of Sichuan province in China is selected as a study area. Multitemporal DEM data spanning over 17 years are collected and the topographic variation of the landscape in this area is investigated. Multitemporal susceptibility maps of landslides are subsequently generated using the widely accepted logistic regression model (LRM). A positive correlation between the topographic variation and landslide susceptibility that was supported by previous studies is quantitatively verified. The ratio of the number of landslides to the susceptibility level areas (RNA) in which the hazards occur is introduced. The RNA demonstrates a general decrease in the susceptibility level from 2000 to 2009, while the ratio of the decreased level is more than fifteen times greater than that of the ratio of the increased level. The impact of the multitemporal DEM on susceptibility mapping is demonstrated to be significant. As such, susceptibility assessments should use DEM data at the time of study.
\end{abstract}

Keywords: multitemporal DEM; control factors; susceptibility assessment; LRM; historical landslide events

\section{Introduction}

Geohazards are some of the most uncontrolled impacts on local and global economies, as well as on people's livelihoods. Almost nowhere on the planet is free from the damage of geohazards [1]. An essential component of predicting possible geohazard zones is the identification of an area that is vulnerable to future landslides [2,3]. Landslides are common geohazards that destroy local resources and environments. Therefore, susceptibility assessments of landslides have been widely investigated to improve their capability for use with these hazards $[4,5]$.

Current studies commonly focus on two major issues regarding the susceptibility assessments of landslides-selection of evaluation indices and establishment of a rational assessment model. Relevant reviews [6-9] demonstrate that exiting studies have proposed various remarkable models for susceptibility assessment of landslides, such as logistic regression models (LRMs) [10]. Meanwhile, in recent decades, the rapid development of machine learning algorithms in susceptibility assessments 
has been seen over time. LRMs are some of the most classic and commonly used methods, which have the advantages of minimal computation, high detection speed, and good adaptability [11]. LRMs have extensive applications in forecasting [12,13] and susceptibility assessment $[14,15]$. These studies provide a solid foundation for the susceptibility assessment of landslides, and advance the knowledge of susceptibility assessment with machine learning algorithms.

In addition to an assessment model, the rational selection of indices is quite important for susceptibility assessment of landslides. Generally, indices such as lithology, elevation, and topography are introduced as the controlling factors, which are strongly related to the susceptibility assessment of landslides [16-20]. The rational selection of these indices remains a subject of scientific debate in many studies because the importance of different indices may vary from case to case. A review of previous studies [21] provides a guideline for addressing this issue. However, the generalizability of these results is subject to certain limitations, while another essential problem regarding the temporal variation of indices and the influence of this on susceptibility is still confusing and requires more attention. The susceptibility result will be questionable if the data for one index is out of date owing to the absence of a current data source, which is the case in digital elevation models (DEMs). So far, however, few researchers have highlighted the impact of outdated data sources on the reliability of susceptibility results, and few previous studies have investigated the mechanisms involved.

A DEM is the digital representation of a terrain surface. These models have been widely applied in geohazard planning, terrain surface analysis, and other fields [22]. Generating a DEM generally involves data from different sources [23], including global multiresolution topography (GMRT) models, shuttle radar topography mission digital elevation models, and advanced space-borne thermal emission and reflection radiometer global digital elevation models (ASTER GDEMs).

Among the abovementioned indices, elevation, topography, and slope are closely related to the DEM data [24]. In the majority of the previous studies, it has been suggested that DEM data should be consistent with the study date [25-29]. However, because of landscape changes and reshaping processes (e.g., earthquakes and engineering construction), the DEM data usually show obvious temporal variation. An example of significant temporal variation of DEM data was shown by Cucchiaro et al., who substantiated that the DEM difference of the eastern Italian Alps within one month is up to $0.14 \mathrm{~m}$ [30]. Pineux et al. demonstrated that the changes experienced by a DEM over time are obvious and unpredictable [31]. DEM data have significant influence on susceptibility assessments of landslides, mainly through influencing factors such as elevation, topography, and slope. Elevation is one of the most influential factors controlling landslide occurrences in a study area, while topography and slope are also important in susceptibility assessments $[18,29,32]$. However, studies have not considered the obvious temporal variation in DEMs.

In the present paper, multitemporal DEMs area are obtained for the study and the elevation changes demonstrated in the DEMs are analyzed. The DEM data for three years (1992, 2000, and 2009) are used to analyze factors affected by a DEM. The susceptibility results for the three years are evaluated using the different DEM-dependent factors and the same DEM-independent factors. Quantifying the index, the susceptibility assessments are then obtained using a generally accepted LRM model. Additionally, the maps of susceptibility levels in the study area are obtained within the geographic information system (GIS). The influence of DEM data at different times on a susceptibility assessment and the influence of the specific values of the elevation differences on the assessment level are obtained. Meanwhile, the impact of historical landslide events on the susceptibility assessment is analyzed. The study aims to achieve a better evaluation of the impact of multitemporal factors on the susceptibility assessment of landslides. 


\section{Study Area}

\subsection{Study Area and Landslide Data}

The southern area of Sichuan province in China is a region with frequently occurring landslides. The study area covers the three districts of Panzhihua, Liangshan, and Ya'an (Figure 1). The area is located at a latitude of $26^{\circ} 03^{\prime}-30^{\circ} 56^{\prime}$ north and a longitude of $100^{\circ} 03^{\prime}-103^{\circ} 52^{\prime}$ east. The area also belongs to the Sichuan Basin, adjacent to the Qinghai-Tibet Plateau in the west. It has a complex topography mainly composed of plains, hills, mountains, and plateaus; furthermore, the relative elevation is more than $3200 \mathrm{~m}$.
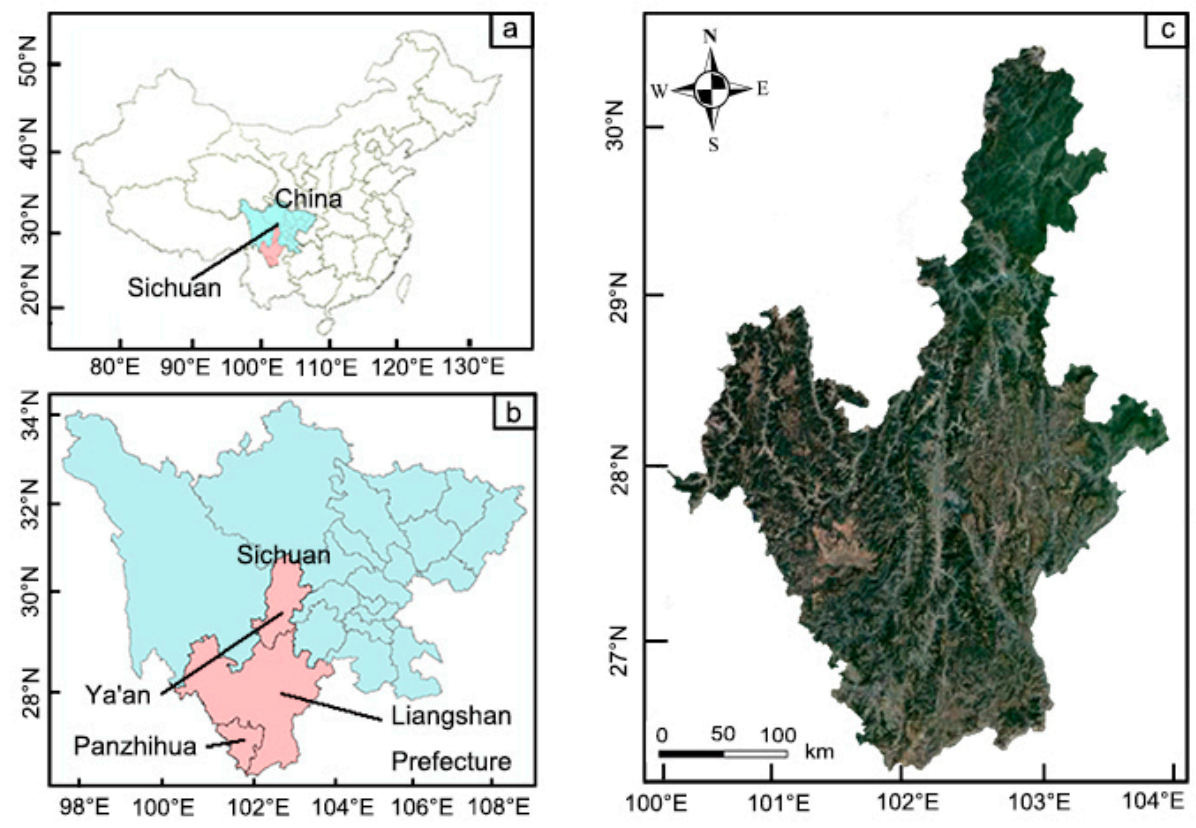

Figure 1. Location of the study area: (a) Sichuan province in China; (b) the study area; (c) an aerial photograph of the study area.

The climate in the study area is a typically humid subtropical monsoonal climate that is hot in summer and mild and humid in winter, with plentiful rainfall and mist. The vertical climate differs greatly, and the annual average temperature distribution gradually increases from northwest to southeast. The average temperature ranges from 5.3 to $15.7^{\circ} \mathrm{C}$, with annual average rainfall ranging from 1500 to $1800 \mathrm{~mm}$. The study area is, therefore, extremely rainy. The rainfall is mainly concentrated from June to October, which accounts for approximately $70 \%-75 \%$ of the annual rainfall. The maximum daily precipitation reaches $300-500 \mathrm{~mm}$. Meanwhile, part of the study area is located in the Himalaya earthquake zone, which suffers from permafrost, avalanches, and landslides. The stratum of the study area is complete (from Archean to Quaternary). The dominant lithology is sedimentary rock, majorly consisting of dolomite, limestone, siliceous rock, shale, and sandstone [33]. The surface water system is developed, and there are many tributaries of the Yangtze River. The groundwater is distributed widely and buried shallowly, which is affected significantly by the rainfall and landform [34].

The Chinese Geological Environment Monitoring Institute collected the landslides information in this region through the China Geological Survey, including locations and occurrence times, and released it to public in its Bulletin of National Geological Hazards [35]. The annual total number of historical landslide events is shown in Figure 2. More than $85 \%$ of the historical landslide events were induced by natural environmental factors, such as rainfall and earthquakes, while only a few events were induced by human factors, such as mining and slope cutting. As the source data in the Bulletin of National Geological Hazards are not distinguished by landslide type, the general landslides analyzed in the study are of various types. 


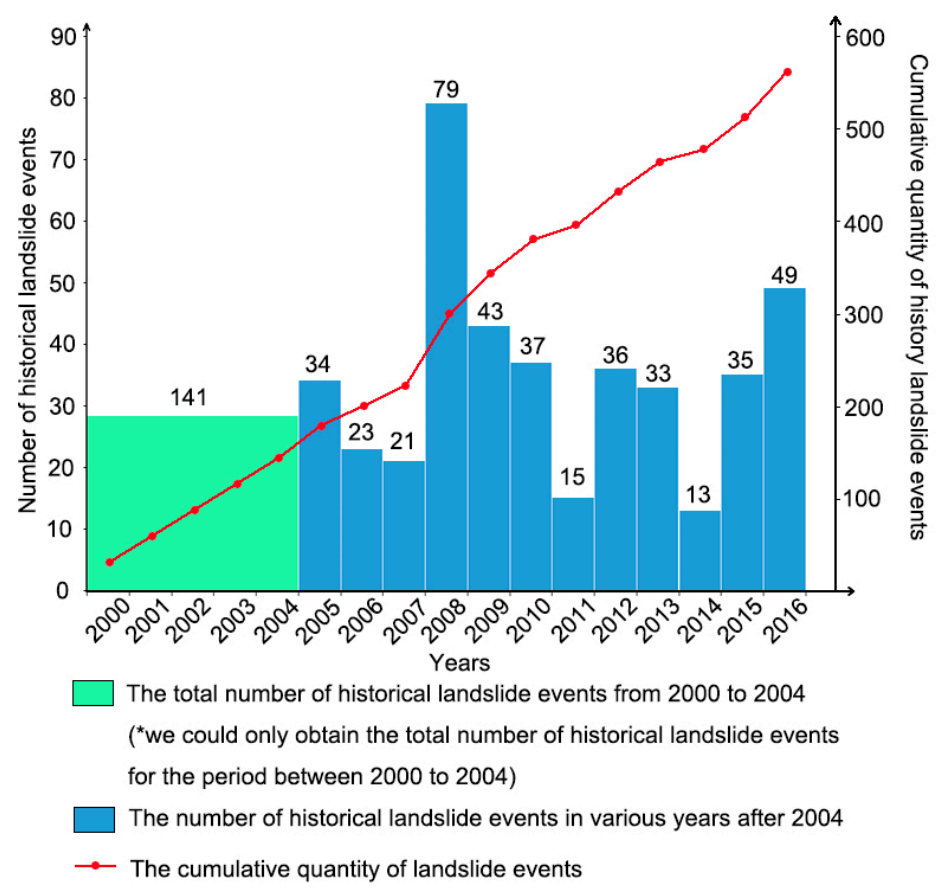

Figure 2. Number of historical landslide events in various years.

In this study, the total number of historical landslide events from 2000 to 2016 and the number of those hazards in various years after 2004 are obtained. However, we can only obtain the total number of historical landslide events for the period between 2000 and 2004. Thus, to better analyze the impact of a DEM on susceptibility assessment, we divide the historical landslide events into two broad types: the landslide events during the period ranging from 2000 to 2009, and the period ranging from 2010 to 2016. The historical landslide events in the study area from 2000 to 2009 and from 2010 to 2016 (Figure 3) can be obtained from the China Geological Environment Information database (http://www.cigem.cn). A total of 341 historical landslide events from 2000 to 2009 and 218 historical landslide events from 2010 to 2016 were recorded.

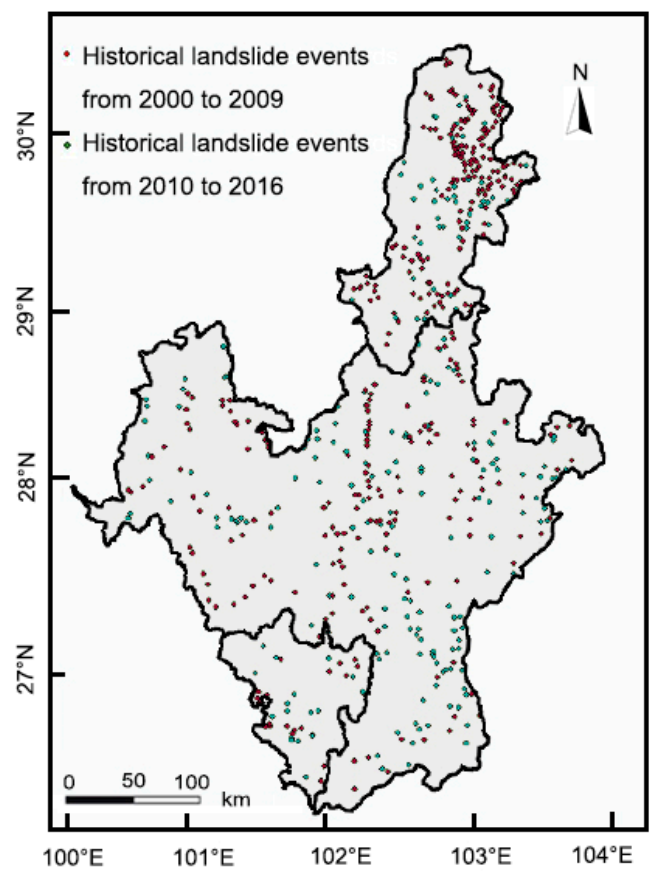

Figure 3. Locations of historical landslide events. 


\subsection{Influencing Factors}

Selecting the influencing factors is a key step in a landslide susceptibility assessment [36,37]; however, the causes of landslides are complex. To date, hundreds of influencing factors have been identified that are potentially important to susceptibility assessments [38]. For example, areas with high elevation and steep slopes are highly prone to landslides [39]. Lithology is also related to landslide occurrences, because different lithologies can withstand different levels of triggering factors. The distances to structure lines, rivers, and roads have important impacts on the spread and size of landslides in the study area [40]. Pourghasemi et al. investigated global susceptibility during the period of 2005-2016 [28]. Nearly 100 factors were summarized to reveal the commonly used factors. In accordance with the relevant studies $[29,41,42]$ and the study area, we select eight influencing factors: elevation, topography, slope, lithology, distance to a structure line, distance to a river, average annual rainfall, and distances to roads.

Table 1 lists all the DEM data for the study area and their sources. The Open Topography Facility provided the GMRT data, which is hosted at the San Diego Supercomputer Center, University of California San Diego. This facility has built a strong cyberinfrastructure framework for managing and processing high-resolution topography data from light detection and ranging (LiDAR) (http://opentopo.sdsc.edu/datasets?listAll=true). Meanwhile, the Shuttle Radar Topography Mission (SRTM) DEM and Global Digital Elevation Model (GDEM) DEM were provided by the Geospatial Data Cloud site of the Computer Network Information Center in the Chinese Academy of Sciences (http://www.gscloud.cn/). The DEM data at the same resolution for 1992, 2000, and 2009 were then obtained using a resampling tool in the GIS environment (Figure 4). There are three resampling methods in the resampling tool, namely nearest neighbor, bilinear interpolation, and cubic convolution methods. Nearest neighbor is selected in the present study because the method is simple, fast, and applicable.

Table 1. Digital elevation model (DEM) data used in this study and their sources.

\begin{tabular}{cccccc}
\hline DEM Data & Survey Date & Data Type & Resolution & Coordinates & Source \\
\hline GMRT * Data $^{\text {Synthesis }}$ & 1992 & KML & $90 \mathrm{~m}$ & WGS84 & Open Topography \\
SRTM ${ }^{* *}$ DEM & 2000 & IMG & $90 \mathrm{~m}$ & UTM/WGS84 & Geospatial Data Cloud site \\
GDEM *** & 2009 & IMG & $30 \mathrm{~m}$ & UTM/WGS84 & Geospatial Data Cloud site \\
DEM & & & & & \\
\hline
\end{tabular}

${ }^{*}$ GMRT is short for Global Multi-Resolution Topography. ${ }^{* *}$ SRTM is short for Shuttle Radar Topography Mission. *** GDEM is short for Global Digital Elevation Model.

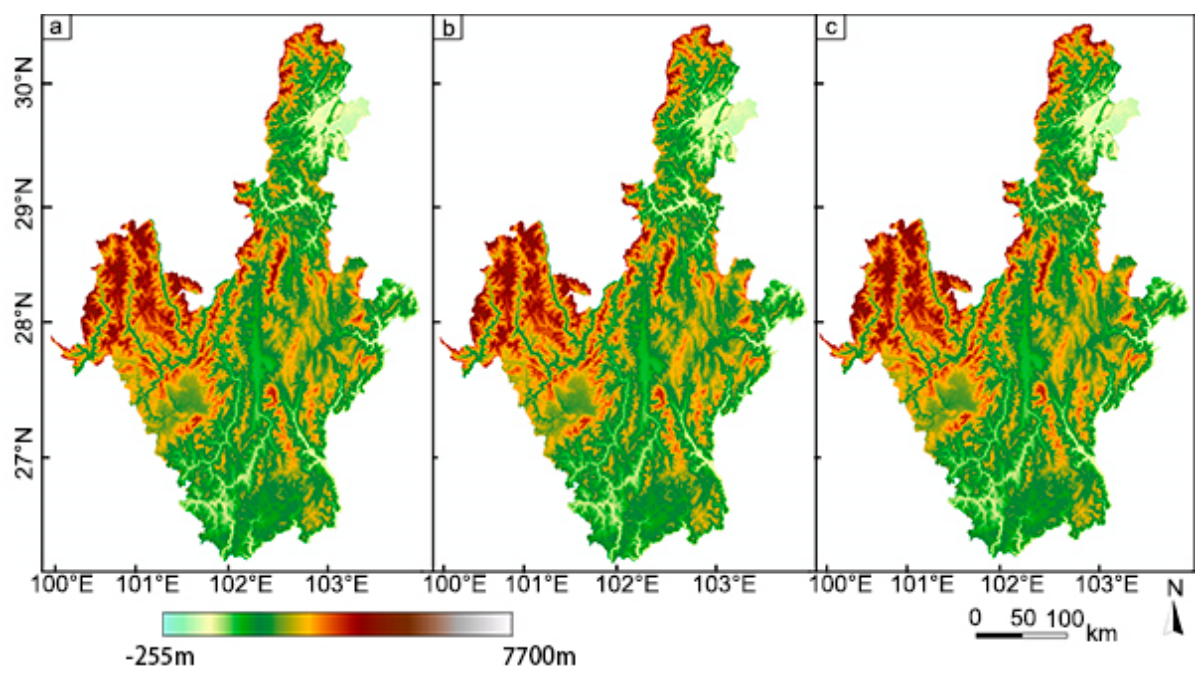

Figure 4. DEM data for the study area in (a) 1992, (b) 2000, and (c) 2009. 
The DEM data for 1992, 2000, and 2009 were used to analyze factors affected by the DEM. Meanwhile, the data of other factors, namely lithology, distance to the structure line, distance to the river, and average annual rainfall, remained the same and were provided by China Railway Number 4 Engineering Group Co., Ltd. (745 Heping Road, Wuhan, Hubei, China), and the Roads and Traffic Authority of China. Because of the diversity of lithological layers in the study area, the lithology is divided into four groups in Table 2 [43]. Thus, the zoning maps of the four factors were obtained (Figure 5).

Table 2. Lithology and structure in the study area.

\begin{tabular}{ccc}
\hline Groups & Structure & Lithology \\
\hline Group 1 & Loose structure & Clay, gravelly soil, clay rock, thin layer siltstone \\
Group 2 & Cataclastic structure & Siltstone, shale, phyllite, thin layer slate \\
Group 3 & Stratified structure & $\begin{array}{c}\text { Thick layer sandstone, conglomerate with argillaceous rocks, } \\
\text { siliceous rock with argillaceous shale }\end{array}$ \\
Group 4 & Block structure & Limestone, siliceous rock, thick layer conglomerate, \\
& dolomite, phosphate rock
\end{tabular}

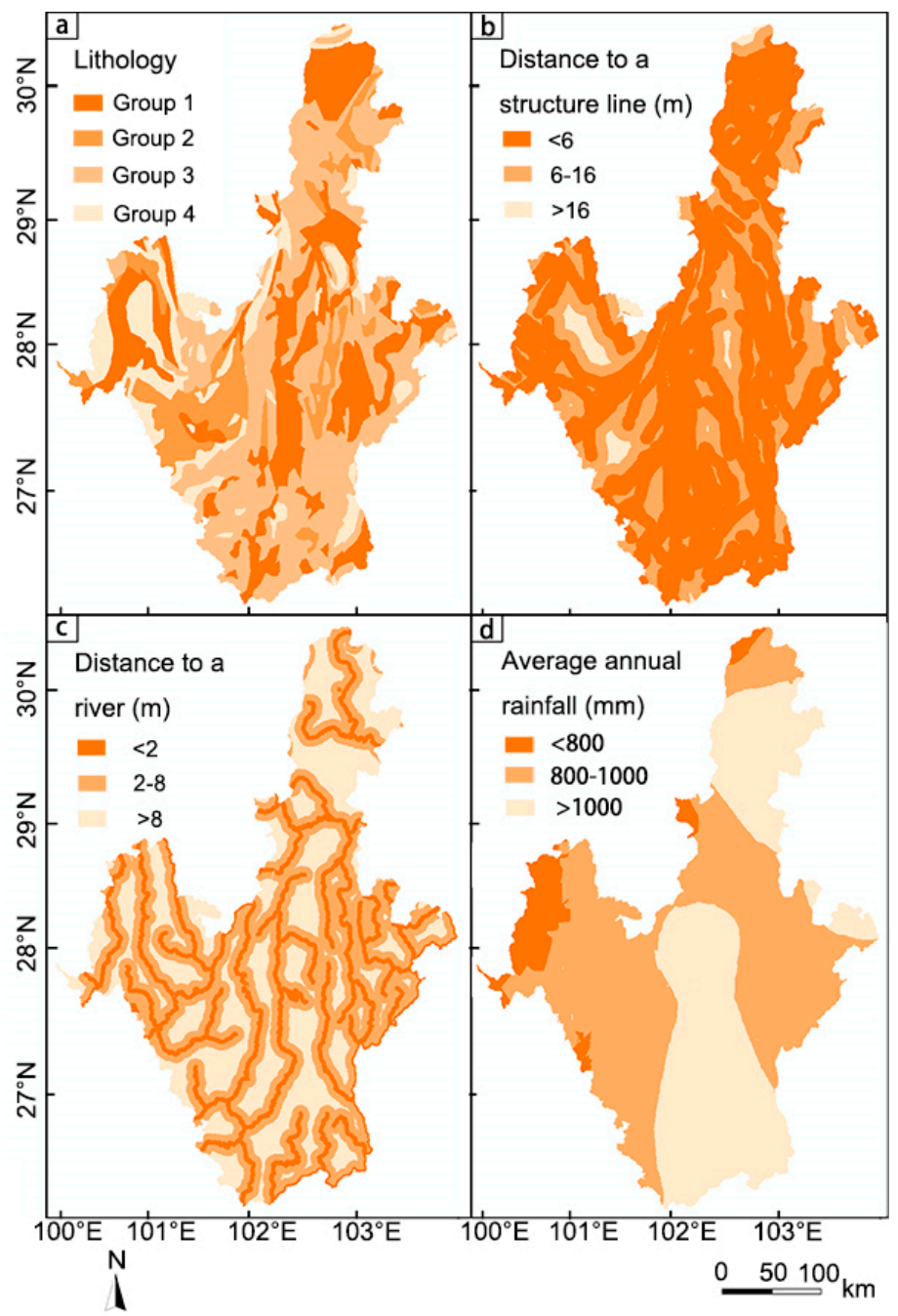

Figure 5. Zoning map of (a) lithology, (b) distance to a structure line, (c) distance to a river, (d) and average annual rainfall. 


\section{Methodology}

\subsection{Flowchart}

The research methodologies applied in the present study are as shown in Figure 6. The flowchart consists of four major steps, as follows:

(a) Data preparation. The multitemporal DEM data, influencing factors, and historical landslide events are prepared;

(b) Data preprocessing. The multitemporal DEM data is compared to eliminate the noise based on coverage probabilities for confidence intervals;

(c) Susceptibility assessment of landslides. The assessment results for 1992, 2000, and 2009 are obtained using a LRM;

(d) Comparison and analysis. The assessment results for 1992, 2000, and 2009 are compared to obtain the impacts of the elevation difference and the historical landslide events on the susceptibility assessment.

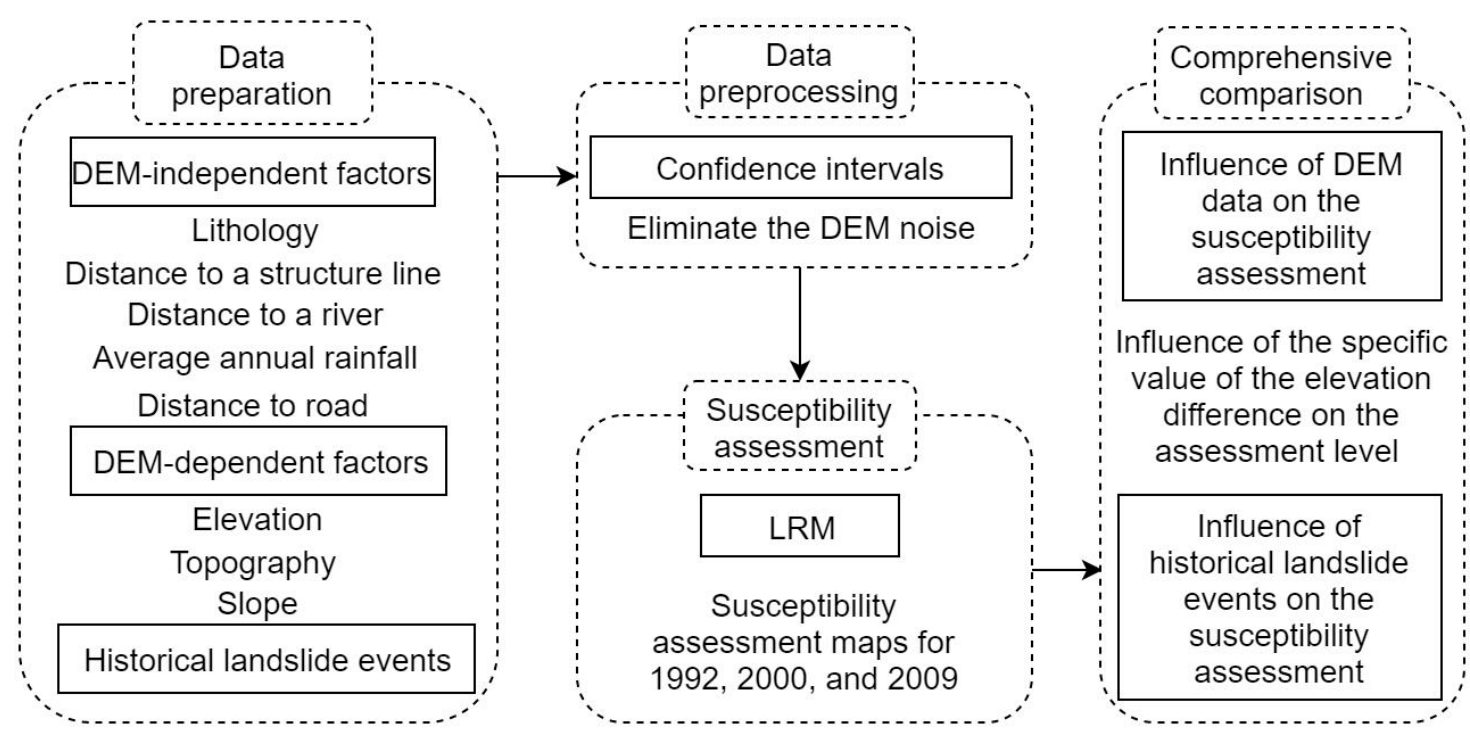

Figure 6. Methodology of research applied in this study. LRM-logistic regression model.

\subsection{Confidence Interval}

In the present study, because of the noise in the DEM data reducing the accuracy of data analysis significantly, not all DEM data are reliable. Therefore, the noise needs to be eliminated to determine the reliability of the DEM data. The confidence level of the DEM data is assessed to improve the accuracy of data analysis.

The confidence interval is a commonly-used interval estimation method used for sample statistics, which shows the confidence probability of the measured parameter value [42,44]. The elevation difference is considered as the sample data in the present study. The average value of elevation difference is $\mu$, and the standard deviation is $\sigma$. The confidence probability is obtained as follows:

$$
\operatorname{Pr}\left(c_{1} \leq \mu<c_{2}\right)=1-\alpha
$$

where $\alpha$ is the significance level and the interval $\left(c_{1}, c_{2}\right)$ is the confidence interval. Therefore, the confidence interval of the average value is $\left(\mu-\sigma Z_{\alpha / 2}, \mu+\sigma Z_{\alpha / 2}\right)$, where $=Z_{\alpha / 2}$ is the corresponding standard score. In general, the confidence probability in the literature $[42,45,46]$ is $90 \%$ or $95 \%$, and $Z_{\alpha / 2}$ is 1.645 or 1.96 , respectively. 


\section{3. $L R M$}

The LRM is a statistical model used to predict the probability of a categorical occurrence using one or more independent variables [47]. The purpose of LRM is to obtain the relationship between a dependent variable and multiple independent variables that have been identified.

In the present study, the independent variables are the influencing indices of landslides, and the dependent variable is the probability of the landslide occurring. By transforming the universal formula of LRM, $Y$ is obtained:

$$
Y=C_{0}+\sum_{i=1}^{n} C_{i} I_{i}
$$

where $C_{0}$ is the LRM constant coefficient, $C_{i}$ is the LRM coefficient, $I_{i}$ is the landslide index, $\mathrm{Y}=\ln (\mathrm{P} /(1-\mathrm{P}))$, and $P$ is the probability of the landslide occurring. The LRM coefficient $C_{i}$ and the LRM formula can be obtained using Statistical Product and Service Solutions (SPSS) software.

\subsection{Ratio of Number of Landslides to Area (RNA)}

$R N A$ denotes the ratio of the number of historical landslide events to the area of the susceptibility levels at which historical landslide events are located. The RNA of the level $i$ is obtained with the following equation:

$$
R N A_{i}=n_{i} / A_{i}
$$

where $R N A_{i}$ is the number of landslides per area at a particular level $i ; n_{i}$ is the number of historical landslide events at level $i$; and $A_{i}$ is the area of level $i$ in the assessment.

\section{Results}

\subsection{Elimination of Noise}

As mentioned above, the DEM has a significant effect on susceptibility assessment through three indices, namely elevation, topography, and slope. The changes in the DEM from 1992 to 2000 and from 2000 to 2009 are obtained to explore the impact of the temporal variation of DEM data on susceptibility assessment. Meanwhile, the average values and standard deviation of the elevation differences are obtained from the topography changes revealed by the DEM data. The confidence probability is considered as $95 \%$ in this study. The corresponding standard scores and confidence intervals are, therefore, calculated (Table 3). After the noise is eliminated, the optimized map of topography changes from 1992 to 2000 and from 2000 to 2009 are obtained (Figure 7).

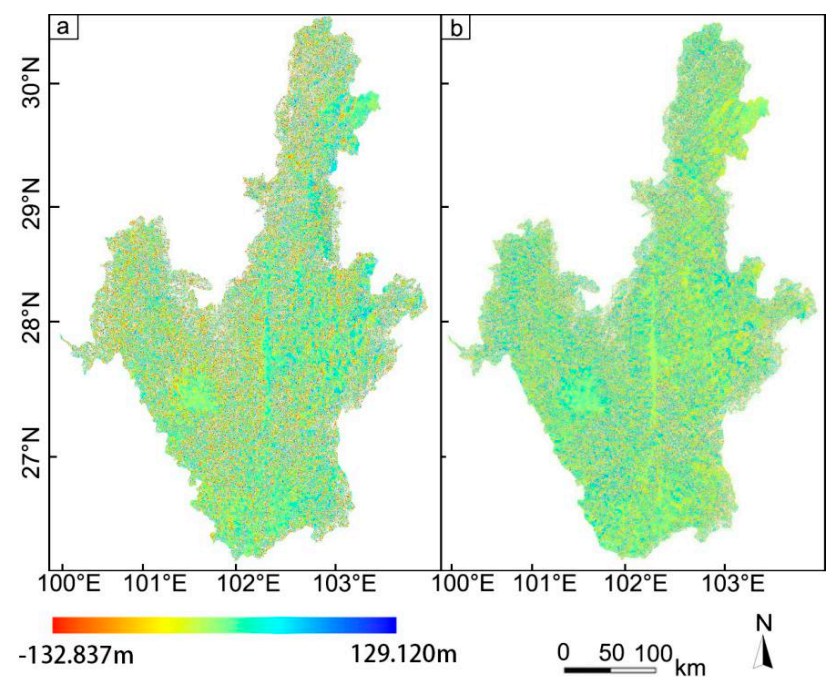

Figure 7. Topography changes revealed by the DEM data: (a) from 1992 to 2000; (b) from 2000 to 2009. 
Table 3. Confidence interval of elevation differences for the periods ranging from 1992 to 2000 and from 2000 to 2009.

\begin{tabular}{ccccc}
\hline Data & Average Value (m) & $\begin{array}{c}\text { Standard } \\
\text { Deviation }(\mathbf{m})\end{array}$ & Standard Score & $\begin{array}{c}\text { Confidence } \\
\text { Interval (m) }\end{array}$ \\
\hline From 1992 to 2000 & -1.859 & 66.826 & 1.960 & $(-132.837,129.120)$ \\
From 2000 to 2009 & 0.965 & 59.204 & 1.960 & $(-115.075,117.005)$ \\
\hline
\end{tabular}

\subsection{Susceptibility Assessments of Landslides}

The susceptibility assessment maps of the study area in 1992, 2000, and 2009 are obtained in the GIS environment using LRM (Figure 8 and Table 4). The susceptibility is classified into four levels based on the natural breaks classification (NBC) method, which is based on natural groupings inherent in data. The NBC identifies groups of similar values and maximizes the differences between classes. The features are divided into classes whose boundaries are set based on relatively big differences in the data values. Here, level I, level II, level III, and level IV denote low, moderate, high, and very high susceptibility, respectively. The area percentages of various susceptibility levels in the study are shown in Table 4.

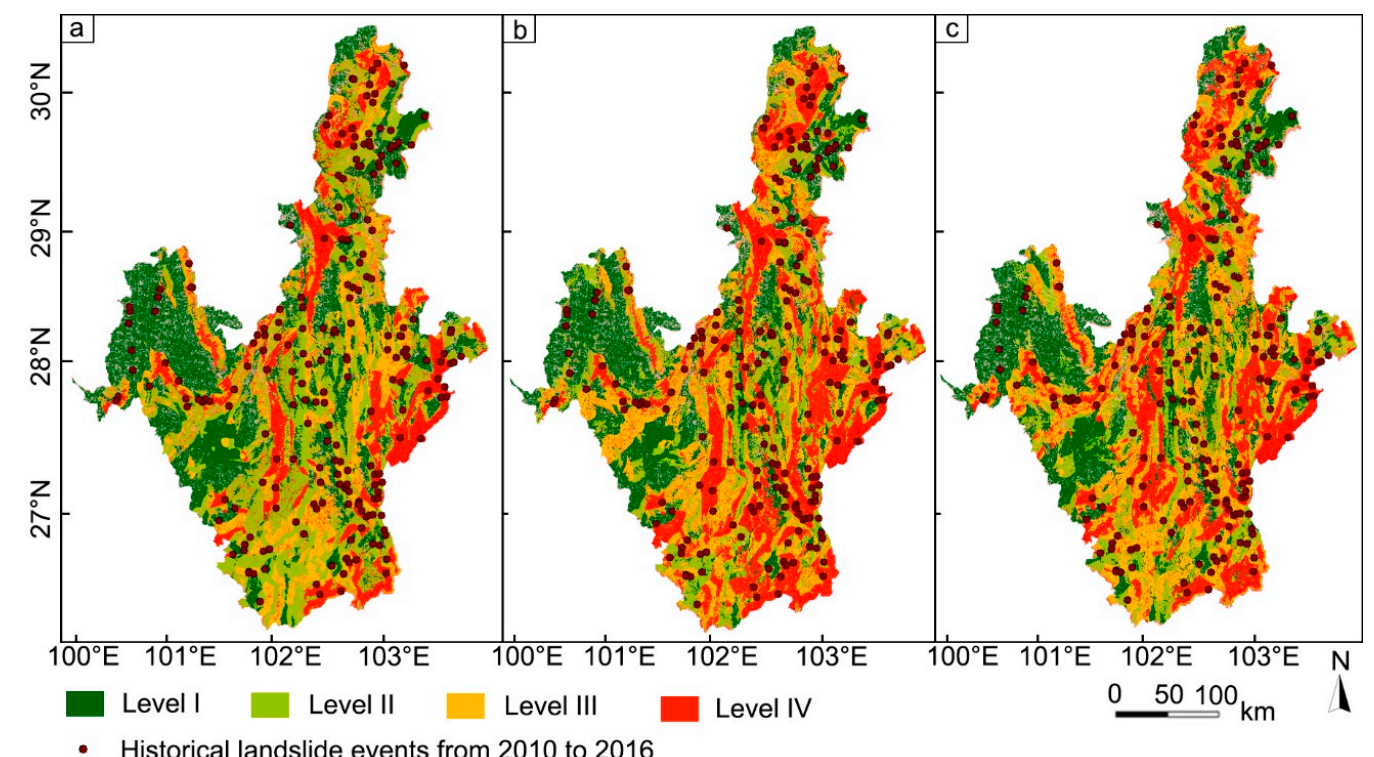

Figure 8. Susceptibility assessment maps for (a) 1992, (b) 2000, and (c) 2009.

Table 4. Susceptibility assessment of landslides using LRM scores.

\begin{tabular}{|c|c|c|c|c|c|c|}
\hline \multirow{2}{*}{$\begin{array}{l}\text { Susceptibility } \\
\text { Level }\end{array}$} & \multicolumn{2}{|c|}{1992} & \multicolumn{2}{|c|}{2000} & \multicolumn{2}{|c|}{2009} \\
\hline & $\begin{array}{c}\text { Area } \\
\left(10^{3} \mathrm{~km}^{2}\right)\end{array}$ & $\begin{array}{c}\text { Percentage } \\
(\%)\end{array}$ & $\begin{array}{c}\text { Area } \\
\left(10^{3} \mathrm{~km}^{2}\right)\end{array}$ & $\begin{array}{c}\text { Percentage } \\
(\%)\end{array}$ & $\underset{\left(10^{3} \mathrm{~km}^{2}\right)}{\text { Area }}$ & $\begin{array}{c}\text { Percentage } \\
(\%)\end{array}$ \\
\hline Level I & 26.445 & 34.23 & 22.342 & 28.91 & 23.378 & 30.21 \\
\hline Level II & 26.127 & 33.82 & 17.969 & 23.25 & 15.781 & 20.39 \\
\hline Level III & 13.573 & 17.57 & 17.128 & 22.16 & 20.747 & 26.81 \\
\hline Level IV & 11.116 & 14.39 & 19.842 & 25.68 & 17.473 & 22.58 \\
\hline
\end{tabular}

As shown in Figure 8 and Table 4, the results of the susceptibility assessment vary from year to year. The areas with low and moderate susceptibility (levels I and II, respectively) in 1992 are the largest, while the area with very high susceptibility (level IV) is the largest in 2000. The rapid decrease in the level IV area from 2000 to 2009 is noticeable. One possible explanation for the decrease is that the 
slopes where landslides occurred became stable in the short term, owing to the excessive landslides that occurred from 2000 to 2009; thus, the susceptibility level of the study area decreased after the hazards.

The susceptibility maps are obtained using different DEM-dependent factors, while the DEM-independent factors are constant in the assessment. Comparing these results illustrates the significant influence of the DEM data from different years on the susceptibility assessment.

\subsection{Assessment Levels of Historical Landslide Events}

Figure 8 and Table 5 show the susceptibility assessment levels at which historical landslide events occurred from 2010 to 2016.

Table 5. Historical landslide event levels.

\begin{tabular}{ccccccc}
\hline $\begin{array}{c}\text { Susceptibility } \\
\text { Level }\end{array}$ & \multicolumn{2}{c}{$\mathbf{1 9 9 2}$} & \multicolumn{2}{c}{$\mathbf{2 0 0 0}$} & \multicolumn{2}{c}{$\mathbf{2 0 0 9}$} \\
\cline { 2 - 6 } & Number & $\begin{array}{c}\text { RNA * } \\
\left(\mathbf{1 0}^{\mathbf{3}} \mathbf{k}^{\mathbf{2}}\right)\end{array}$ & Number & $\begin{array}{c}\text { RNA } \\
\left(\mathbf{1 0}^{\mathbf{3}} / \mathbf{k m}^{\mathbf{2}}\right)\end{array}$ & Number & $\begin{array}{c}\text { RNA } \\
\left(\mathbf{1 0}^{\mathbf{3}} / \mathbf{k m}^{\mathbf{2}}\right)\end{array}$ \\
\hline Level I & 33 & 1.25 & 34 & 1.52 & 26 & 1.11 \\
Level II & 79 & 3.02 & 44 & 2.45 & 38 & 2.41 \\
Level III & 53 & 3.90 & 60 & 3.50 & 59 & 2.84 \\
Level IV & 53 & 4.77 & 80 & 4.03 & 95 & 5.44 \\
\hline
\end{tabular}

${ }^{*}$ RNA denotes the ratio of number of landslides to area.

It can be clearly seen in Table 5 that the combined number of historical landslide events designated as levels III and IV is 106, 140, and 154, respectively, in 1992, 2000, and 2009. The RNA for level IV in 2009 is $5.44 \times 10^{-3} / \mathrm{km}^{2}$, which is the largest among the RNA values over the three years. The most ideal assessment of landslides would be most landslides occurring in level IV areas. There is a significant positive correlation between the RNA and the accuracy of the assessment. Therefore, the results of the susceptibility assessment using the DEM for 2009 are more accurate than the results using the DEM for 1992 and 2000.

It is apparent from Table 5 that the small change in elevation over time has a great influence on the susceptibility assessment of landslides. However, in previous research, the survey data are not explained or the data are significantly different from the assessment time.

\subsection{Differences between the Assessment Levels}

Comparisons are performed using the susceptibility assessments of landslides in the study area from different periods. Figure 9 and Table 6 compare the differences between the assessment results for 1992 and 2000 and between those for 2000 and 2009, showing that the area where the level difference is zero is the largest area. Meanwhile, the area with increased susceptibility is much larger than the area with decreased susceptibility in the period ranging from 1992 to 2000, which is contrary to the results for the period ranging from 2000 to 2009.

Table 6. Differences in the assessment levels.

\begin{tabular}{|c|c|c|c|c|}
\hline \multirow{2}{*}{ Level Difference } & \multicolumn{2}{|c|}{1992 and 2000} & \multicolumn{2}{|c|}{2000 and 2009} \\
\hline & Area $\left(10^{3} \mathrm{~km}^{2}\right)$ & Percentage (\%) & Area $\left(10^{3} \mathrm{~km}^{2}\right)$ & Percentage (\%) \\
\hline-3 & 0.041 & 0.053 & 0.516 & 0.667 \\
\hline-2 & 0.633 & 0.819 & 1.232 & 1.592 \\
\hline-1 & 5.433 & 7.030 & 13.308 & 17.193 \\
\hline 0 & 41.923 & 54.244 & 48.466 & 62.614 \\
\hline 1 & 26.954 & 34.876 & 12.799 & 16.535 \\
\hline 2 & 1.928 & 2.495 & 0.893 & 1.154 \\
\hline 3 & 0.373 & 0.483 & 0.190 & 0.245 \\
\hline
\end{tabular}




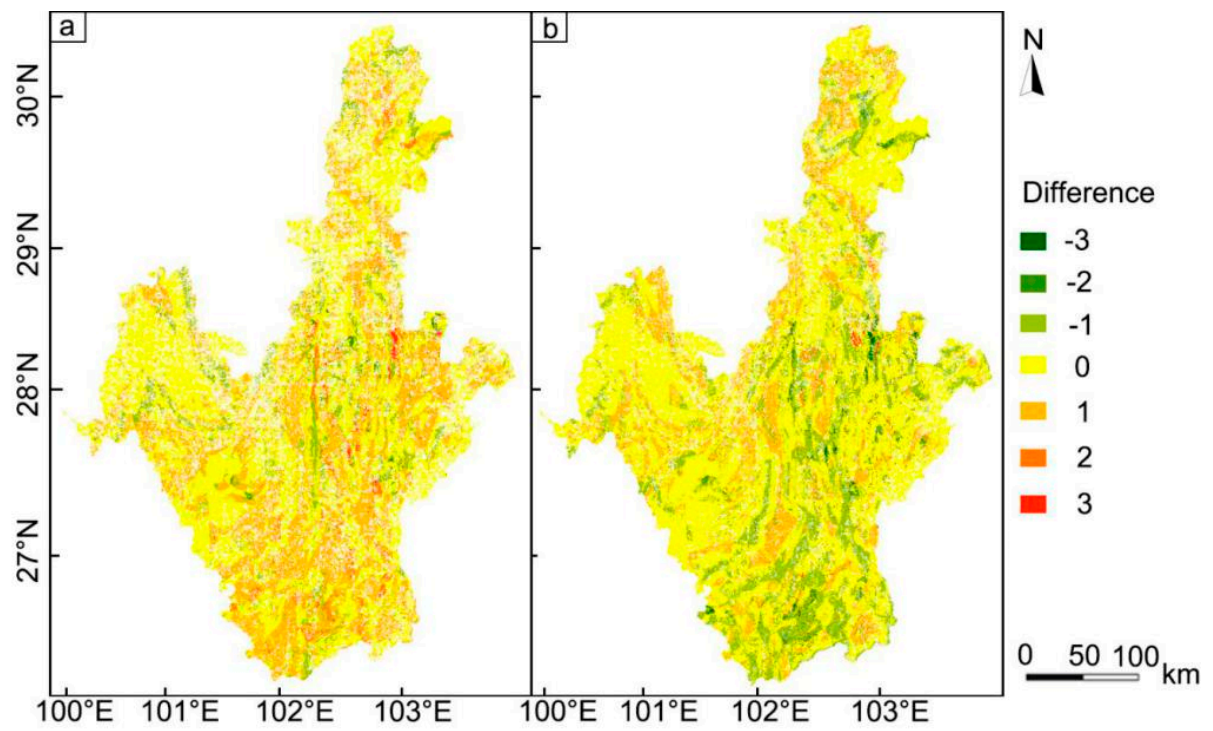

Figure 9. Maps of the differences between the assessment levels: (a) difference between 1992 and 2000; (b) difference between 2000 and 2009.

\section{Discussion}

\subsection{Comprehensive Comparison of Assessment Results for 1992, 2000, and 2009}

We compare the areas and RNA values of various assessment levels for the years 1992, 2000, and 2009 (Figure 10a,b), and the level differences from 1992 to 2000 and from 2000 to 2009 (Figure 10c). Figure 10 is quite revealing in several ways. First, the RNA for level IV in 2009 is larger than that in 1992 or 2000. Because of the positive correlation between the RNA and the accuracy of the assessment, the accuracy of the assessment is further exemplified in studies using the DEM for 2009. As Figure 10c shows, there is a significant difference between the two results. The area with increased susceptibility in the period ranging from 1992 to 2000 is larger than that in in the period ranging from 2000 to 2009. The observed increase in the area with increased susceptibility could be attributed to the frequent landslides from 2000 to 2009 (e.g., the various landslides caused by the 2008 earthquake).

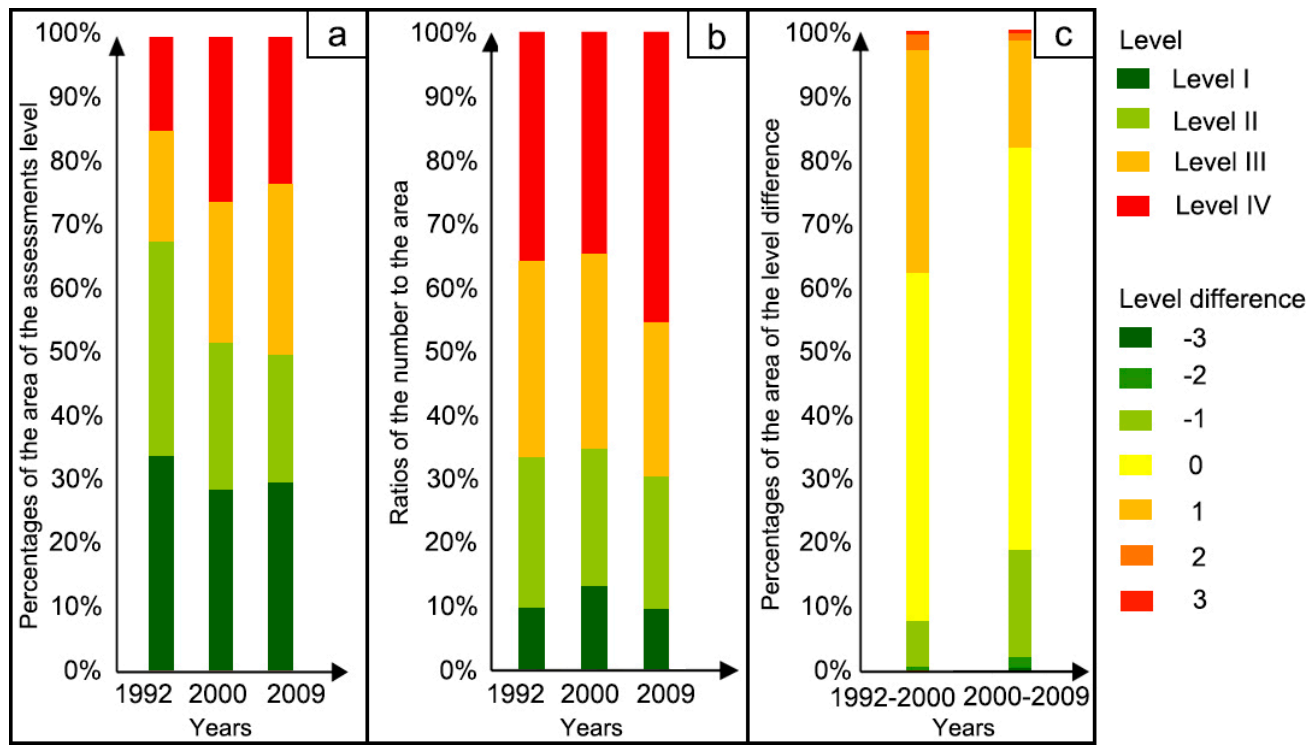

Figure 10. Comprehensive comparison of the percentages of (a) the assessment levels, (b) the RNA values of various assessment levels, and (c) the level differences. 


\subsection{Impact of Elevation Difference on the Susceptibility Assessment}

In addition to the above analysis, we analyze the impact of elevation differences on the susceptibility assessment and the relationships between the elevation differences and the differences in assessment levels. Therefore, the areas with varying level and elevation differences are presented (Table 7).

Table 7. Numbers of historical landslide events at various assessment levels from 1992 to 2000 and from 2000 to 2009.

\begin{tabular}{|c|c|c|c|c|c|c|c|c|c|}
\hline & \multirow{2}{*}{ Area $\left(\mathrm{km}^{2}\right)$} & & \multicolumn{7}{|c|}{ Level Difference } \\
\hline & & & -3 & -2 & -1 & 0 & 1 & 2 & 3 \\
\hline \multirow{14}{*}{$\begin{array}{l}\text { Elevation } \\
\text { differences } \\
(\mathrm{m})\end{array}$} & \multirow{7}{*}{$\begin{array}{l}\text { From } 1992 \\
\text { to } 2000\end{array}$} & $\begin{array}{c}-140 \text { to } \\
-100\end{array}$ & 1.30 & 9.26 & 104.72 & 774.13 & 392.15 & 17.64 & 2.48 \\
\hline & & -100 to -60 & 3.26 & 37.75 & 357.01 & 2921.89 & 1763.27 & 101.98 & 15.73 \\
\hline & & -60 to -20 & 7.41 & 123.31 & 938.88 & 8591.50 & 5593.55 & 380.83 & 74.53 \\
\hline & & -20 to 20 & 23.08 & 351.42 & 2576.43 & $17,433.58$ & $11,260.52$ & 882.75 & 170.13 \\
\hline & & $20-60$ & 4.74 & 85.47 & 1016.90 & 8718.41 & 5753.17 & 417.77 & 85.52 \\
\hline & & 60-100 & 1.19 & 20.40 & 352.12 & 2867.55 & 1774.61 & 105.39 & 21.12 \\
\hline & & 100-1400 & 0.38 & 5.49 & 92.77 & 667.04 & 444.31 & 22.78 & 4.15 \\
\hline & \multirow{7}{*}{$\begin{array}{c}\text { From } 2000 \\
\text { to } 2009\end{array}$} & $\begin{array}{c}-140 \text { to } \\
-100\end{array}$ & 3.36 & 12.28 & 147.25 & 470.17 & 149.40 & 14.39 & 1.74 \\
\hline & & -100 to -60 & 20.63 & 66.89 & 834.75 & 3121.54 & 955.57 & 58.83 & 13.3 \\
\hline & & -60 to -20 & 90.56 & 246.75 & 2709.11 & $10,030.34$ & 2757.22 & 155.02 & 37.61 \\
\hline & & -20 to 20 & 299.11 & 629.70 & 5964.38 & $20,745.68$ & 4914.82 & 370.04 & 74.94 \\
\hline & & $20-60$ & 88.4 & 228.38 & 2748.58 & 9998.40 & 2771.69 & 202.98 & 40.93 \\
\hline & & 60-100 & 12.2 & 43.28 & 790.68 & 3456.15 & 1050.63 & 79.12 & 18.63 \\
\hline & & $100-1400$ & 1.8 & 4.89 & 113.25 & 644.07 & 199.38 & 13.01 & 2.90 \\
\hline
\end{tabular}

Table 7 demonstrates that the decrease in elevation results in a decrease in the susceptibility assessment level. There is a positive correlation between the elevation difference and the difference in the assessment level. Regardless of the level difference, the elevation difference is much larger in the area ranging from -20 to $20 \mathrm{~m}$ than in other areas.

\subsection{Impact of Historical Landslide Events on Susceptibility Assessment}

Most of the factors influencing susceptibility assessments have been explored in several studies [48-50]. However, much of the historical research overlooks the impact of historical landslide events on the assessment [51]. In contrast, because the slopes where landslides occur become stable in the short term following these events, the susceptibility of the area will consequently decrease. Therefore, historical landslide events have a significant effect on susceptibility assessments.

The numbers and percentages of historical landslide events at various assessment levels from 2000 to 2009 and the RNA values of the various assessment levels are investigated, allowing the change in the assessment levels of the historical landslide events to be obtained (Table 8 and Figure 11).

In Figure 11, the circles represent the percentages of historical landslide events or the RNA values at various assessment levels. It can be seen from Figure 11 that over one-third of the historical landslide events $(38.71 \%)$ occur at a decreasing assessment level. A total of $54.24 \%$ of the historical landslide events are within the same assessment level. If the assessment level area is larger, then there may be more historical landslide events within that assessment level. To rule out the possible influence of area size, the RNA is considered to be the most important factor. The RNA at decreased levels $\left(81.31 \times 10^{-3} / \mathrm{km}^{2}\right)$ is more than fifteen times greater than the RNA at increased levels $\left(5.25 \times 10^{-3} / \mathrm{km}^{2}\right)$. Previous studies $[52,53]$ do not take into account the impact of historical landslide events; therefore, the above results can establish the importance of historical landslide events for susceptibility assessments of landslides. 
Table 8. Numbers and percentages of historical landslide events at various assessment levels and RNA values of various assessment levels.

\begin{tabular}{|c|c|c|c|c|c|c|}
\hline & \multirow{2}{*}{ Values } & & \multicolumn{4}{|c|}{2000} \\
\hline & & & Level I & Level II & Level III & Level IV \\
\hline \multirow{12}{*}{2009} & \multirow{4}{*}{ Number } & Level I & 68 & 25 & 4 & 8 \\
\hline & & Level II & 2 & 35 & 28 & 20 \\
\hline & & Level III & 0 & 13 & 23 & 47 \\
\hline & & Level IV & 0 & 0 & 9 & 59 \\
\hline & \multirow{4}{*}{ Percentage } & Level I & $19.94 \%$ & $7.33 \%$ & $1.17 \%$ & $2.35 \%$ \\
\hline & & Level II & $0.59 \%$ & $10.26 \%$ & $8.21 \%$ & $5.87 \%$ \\
\hline & & Level III & 0 & $3.81 \%$ & $6.74 \%$ & $13.78 \%$ \\
\hline & & Level IV & 0 & 0 & $2.64 \%$ & $17.3 \%$ \\
\hline & \multirow{4}{*}{$\begin{array}{c}\text { RNA } \\
\left(10^{-3} / \mathrm{km}^{2}\right)\end{array}$} & Level I & 3.73 & 6.36 & 5.80 & 15.50 \\
\hline & & Level II & 0.59 & 3.93 & 9.50 & 36.83 \\
\hline & & Level III & 0.00 & 2.69 & 2.57 & 7.31 \\
\hline & & Level IV & 0.00 & 0.00 & 1.97 & 4.77 \\
\hline
\end{tabular}

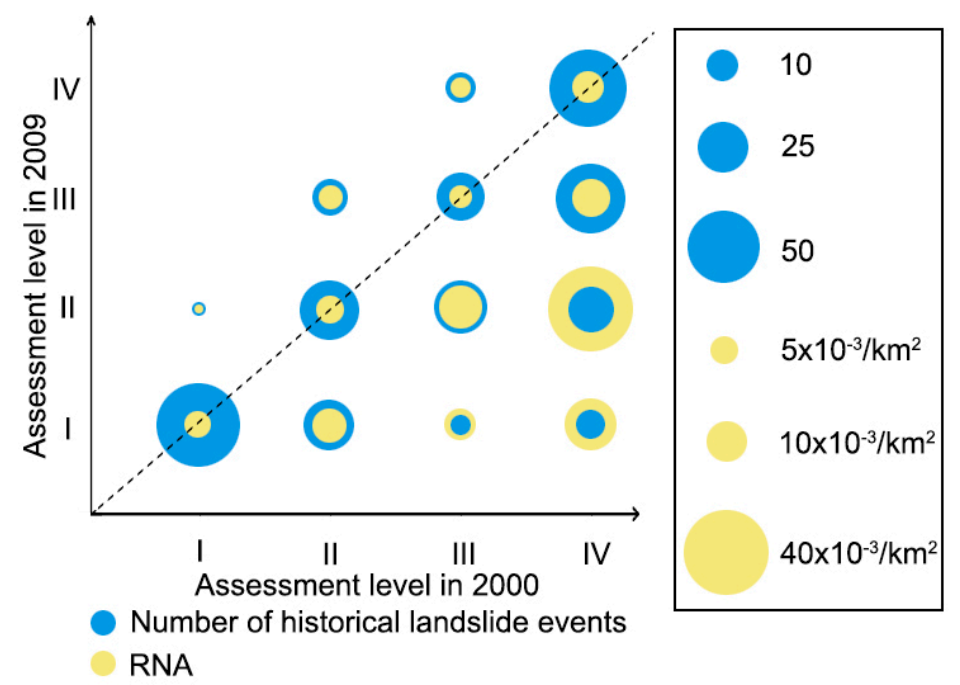

Figure 11. Changes in the assessment levels of historical landslide events from 2000 to 2009.

\subsection{Advantages and Limitations}

The elevation, topography, and slope-depending on the DEM-are usually the main factors affecting susceptibility [23]. The existing studies assume that the influencing factors for susceptibility are constant over time $[15,54]$. However, the DEM data always change significantly over time owing to landscape reshaping, such as landslides and engineering construction $[30,31,55]$. A susceptibility assessment is, therefore, closely related to the data source [56], and as such the susceptibility maps of the study area are not consistent.

Despite this, the existing studies have analyzed the susceptibility of landslides using a single time-related data source without considering whether the date of the data source is consistent with the study date $[57,58]$. Therefore, it is necessary to understand the temporal evolution of influencing factors (e.g., topography) and the influencing mechanisms of the factors on the susceptibility assessment $[59,60]$. The changes in influencing factors are significant in earthquake- and landslide-prone areas [61], such as the study area. Therefore, more research regarding the impacts of factors on the susceptibility of landslides needs to be undertaken. It is better not to evaluate susceptibility simply using constant factors.

The present study performs a preliminarily analysis of the impact of multitemporal DEM on susceptibility and shows that DEM variation has an impact on the susceptibility assessment using DEM-dependent factors. The analysis undertaken here can extend the knowledge regarding the 
impacts of multitemporal data on susceptibility and can aid preliminary studies on the mechanism causing the influence of factor variation.

DEM variation closely relates to local geotechnical properties, which change the susceptibility assessment of landslides. However, the reasons for DEM variation are debated. The mechanism explaining the consequent influences of geotechnical properties on DEM variation remains a scientific challenge. In addition, considering the large spatial extent and period (about 77,000 km², 17 years) in the present study, changes between the three susceptibility maps could not be completely explained by DEM variation. There are also data limitations and difficulties in analyzing the interactions of various factors.

\section{Conclusion}

In the present paper, DEM data for 1992, 2000, and 2009 are obtained to evaluate the susceptibility of landslides. Based on the DEM-dependent factors and the same DEM-independent factors, the susceptibility results are evaluated using LRM.

From the assessment, we find that the results are different by using DEM data from different times. The rapid decrease in the area of level IV from 2000 to 2009 is noticeable. The RNA for level IV in 2009 is larger than in 1992 and 2000. The area of increased susceptibility is much larger than that of decreased susceptibility based on the results of the assessment level differences from 1992 to 2000, which differ from the results from 2000 to 2009.

From the assessment results, we conclude that the DEM data have an impact on the susceptibility assessment in the study area. It is also worth noting that the influences of the specific values of the elevation differences on the assessment results are obtained. Meanwhile, the influence of historical landslide events on the susceptibility assessment is obtained by analyzing the hazard data and the differences between the assessment results. The most obvious finding to emerge from the analysis is that the assessment level of the area with historical landslide events decreases. The present study goes some way towards enhancing our understanding of the impacts and the mechanism of multitemporal factors on susceptibility.

Author Contributions: W.W., Z.H., and G.C. designed the study. J.L. and Y.L. performed the in situ investigation. Z.H. and J.L. wrote the manuscript. All authors have read and agreed to the published version of the manuscript.

Funding: This study was financially supported by the National Key R\&D Program of China (Grant No. 2018YFC1505401), the National Natural Science Foundation of China (Grant No. 51478483, W.D. Wang; and Grant No. 41702310, Z. Han), and the Natural Science Foundation of Hunan (Grant No. 2018JJ3638) These financial supports are gratefully acknowledged. Thanks to the Scholarship of Central South University for Undergraduate Students Studying Abroad.

Conflicts of Interest: The authors declare no conflict of interest.

\section{References}

1. Wang, W.D.; Li, J.Y.; Qu, X.; Han, Z.; Liu, P. Prediction on landslide displacement using a new combinationmodel: A case study of Qinglong landslide in China. Nat. Hazards 2019, 96, 1121-1139. [CrossRef]

2. Han, Z.; Chen, G.Q.; Li, Y.G.; Zhang, H.; He, Y. Elementary analysis on the bed-sediment entrainment by debris flow and its application using the TopFlowDF model. Geomat. Nat. Hazards Risk 2016, 7, $764-785$. [CrossRef]

3. Hong, H.; Pourghasemi, H.R.; Pourtaghi, Z.S. Landslide susceptibility assessment in Lianhua County (China): A comparison between a random forest data mining technique and bivariate and multivariate statistical models. Geomorphology 2016, 259, 105-118. [CrossRef]

4. Patriche, C.V.; Pirnau, R.; Grozavu, A.; Rosca, B. A Comparative Analysis of Binary Logistic Regression and Analytical Hierarchy Process for Landslide Susceptibility Assessment in the Dobrov River Basin, Romania. Pedosphere 2016, 26, 335-350. [CrossRef]

5. Cao, J.; Zhang, Z.; Wang, C.; Liu, J.; Zhang, L. Susceptibility assessment of landslides triggered by earthquakes in the Western Sichuan Plateau. Catena 2019, 175, 63-76. [CrossRef] 
6. Huang, Y.; Zhao, L. Review on landslide susceptibility mapping using support vector machines. Catena 2018, 165, 520-529. [CrossRef]

7. Pham, B.T.; Pradhan, B.; Tien Bui, D.; Prakash, I.; Dholakia, M.B. A comparative study of different machine learning methods for landslide susceptibility assessment: A case study of Uttarakhand area (India). Environ. Model. Softw. 2016, 84, 240-250. [CrossRef]

8. Han, Z.; Chen, G.; Li, Y.; Tang, C.; Xu, L.; He, Y.; Huang, X.; Wang, W. Numerical simulation of debris-flow behavior based on the SPH method incorporating the Herschel-Bulkley-Papanastasiou rheology model. Eng. Geol. 2019, 255, 26-36. [CrossRef]

9. Han, Z.; Chen, G.Q.; Li, Y.G.; Wang, W.; Zhang, H. Exploring the velocity distribution of debris flows: An iterationalgorithm based approach for complex cross-sections. Geomorphology 2015, 241, 72-82. [CrossRef]

10. Li, F.; Wang, W.; Xu, J.; Yi, J.; Wang, Q. Comparative study on vulnerability assessment for urban buried gas pipeline network based on SVM and ANN methods. Process Saf. Environ. Prot. 2019, 122, 23-32. [CrossRef]

11. Pradhan, B.; Lee, S. Delineation of landslide hazard areas on Penang Island, Malaysia, by using frequency ratio, logistic regression, and artificial neural network models. Environ. Earth Sci. 2010, 60, 1037-1054. [CrossRef]

12. Chiri, H.; Abascal, A.J.; Castanedo, S.; Medina, R. Mid-long term oil spill forecast based on logistic regression modelling of met-ocean forcings. Mar. Pollut. Bull. 2019, 146, 962-976. [CrossRef] [PubMed]

13. Zhou, F.; Zhang, Q.; Sornette, D.; Jiang, L. Cascading logistic regression onto gradient boosted decision trees for forecasting and trading stock indices. Appl. Soft Comput. 2019, 84, 105747. [CrossRef]

14. Tsangaratos, P.; Ilia, I. Comparison of a logistic regression and Naïve Bayes classifier in landslide susceptibility assessments: The influence of models complexity and training dataset size. Catena 2016, 145, 164-179. [CrossRef]

15. Lin, G.-F.; Chang, M.-J.; Huang, Y.-C.; Ho, J.-Y. Assessment of susceptibility to rainfall-induced landslides using improved self-organizing linear output map, support vector machine, and logistic regression. Eng. Geol. 2017, 224, 62-74. [CrossRef]

16. Jacobs, L.; Kervyn, M.; Reichenbach, P.; Rossi, M.; Marchesini, I.; Alvioli, M.; Dewitte, O. Regional susceptibility assessments with heterogeneous landslide information: Slope unit- vs. pixel-based approach. Geomorphology 2020, 356, 107084. [CrossRef]

17. Bui, D.T.; Tsangaratos, P.; Nguyen, V.-T.; Liem, N.V.; Trinh, P.T. Comparing the prediction performance of a Deep Learning Neural Network model with conventional machine learning models in landslide susceptibility assessment. Catena 2020, 188, 104426. [CrossRef]

18. Li, Y.; Liu, X.; Han, Z.; Dou, J. Spatial Proximity-Based Geographically Weighted Regression Model for Landslide Susceptibility Assessment: A Case Study of Qingchuan Area, China. Appl. Sci. 2020, 10, 1107. [CrossRef]

19. Mokadem, N.; Boughariou, E.; Mudarra, M.; Ben Brahim, F.; Andreo, B.; Hamed, Y.; Bouri, S. Mapping potential zones for groundwater recharge and its evaluation in arid environments using a GIS approach: Case study of North Gafsa Basin (Central Tunisia). J. Afr. Earth Sci. 2018, 141, 107-117. [CrossRef]

20. Pham, B.T.; Tien Bui, D.; Pham, H.V.; Le, H.Q.; Prakash, I.; Dholakia, M.B. Landslide Hazard Assessment Using Random SubSpace Fuzzy Rules Based Classifier Ensemble and Probability Analysis of Rainfall Data: A Case Study at Mu Cang Chai District, Yen Bai Province (Viet Nam). J. Indian Soc. Remote Sens. 2017, 45, 673-683. [CrossRef]

21. Pourghasemi, H.R.; Teimoori Yansari, Z.; Panagos, P.; Pradhan, B. Analysis and evaluation of landslide susceptibility: A review on articles published during 2005-2016 (periods of 2005-2012 and 2013-2016). Arab. J. Geosci. 2018, 11, 193. [CrossRef]

22. Liu, K.; Song, C.; Ke, L.; Jiang, L.; Ma, R. Automatic watershed delineation in the Tibetan endorheic basin: A lake-oriented approach based on digital elevation models. Geomorphology 2020, 358, 107127. [CrossRef]

23. Deng, F.; Rodgers, M.; Xie, S.; Dixon, T.H.; Charbonnier, S.; Gallant, E.A.; López Vélez, C.M.; Ordoñez, M.; Malservisi, R.; Voss, N.K.; et al. High-resolution DEM generation from spaceborne and terrestrial remote sensing data for improved volcano hazard assessment-A case study at Nevado del Ruiz, Colombia. Remote Sens. Environ. 2019, 233, 111348. [CrossRef]

24. Lee, C.-F.; Huang, W.-K.; Chang, Y.-L.; Chi, S.-Y.; Liao, W.-C. Regional landslide susceptibility assessment using multi-stage remote sensing data along the coastal range highway in northeastern Taiwan. Geomorphology 2018, 300, 113-127. [CrossRef] 
25. Schlögel, R.; Marchesini, I.; Alvioli, M.; Reichenbach, P.; Rossi, M.; Malet, J.P. Optimizing landslide susceptibility zonation: Effects of DEM spatial resolution and slope unit delineation on logistic regression models. Geomorphology 2018, 301, 10-20. [CrossRef]

26. Juliev, M.; Mergili, M.; Mondal, I.; Nurtaev, B.; Pulatov, A.; Hübl, J. Comparative analysis of statistical methods for landslide susceptibility mapping in the Bostanlik District, Uzbekistan. Sci. Total Environ. 2019, 653, 801-814. [CrossRef]

27. Hong, H.; Miao, Y.; Liu, J.; Zhu, A.X. Exploring the effects of the design and quantity of absence data on the performance of random forest-based landslide susceptibility mapping. Catena 2019, 176, 45-64. [CrossRef]

28. He, Q.; Shahabi, H.; Shirzadi, A.; Li, S.; Chen, W.; Wang, N.; Chai, H.; Bian, H.; Ma, J.; Chen, Y.; et al. Landslide spatial modelling using novel bivariate statistical based Naïve Bayes, RBF Classifier, and RBF Network machine learning algorithms. Sci. Total Environ. 2019, 663, 1-15. [CrossRef]

29. Khan, H.; Shafique, M.; Khan, M.A.; Bacha, M.A.; Shah, S.U.; Calligaris, C. Landslide susceptibility assessment using Frequency Ratio, a case study of northern Pakistan. Egypt. J. Remote Sens. Space Sci. 2019, 22, 11-24. [CrossRef]

30. Cucchiaro, S.; Cavalli, M.; Vericat, D.; Crema, S.; Llena, M.; Beinat, A.; Marchi, L.; Cazorzi, F. Geomorphic effectiveness of check dams in a debris-flow catchment using multi-temporal topographic surveys. Catena 2019, 174, 73-83. [CrossRef]

31. Pineux, N.; Lisein, J.; Swerts, G.; Bielders, C.L.; Lejeune, P.; Colinet, G.; Degré, A. Can DEM time series produced by UAV be used to quantify diffuse erosion in an agricultural watershed? Geomorphology 2017, 280, 122-136. [CrossRef]

32. Dou, J.; Yunus, A.P.; Bui, D.T.; Merghad, A.; Sahana, M.; Zhu, Z.F.; Chen, C.W.; Han, Z.; Pham, B.T. Improved landslide assessment using support vector machine with bagging, boosting, and stacking ensemble machine learning framework in a mountainous watershed, Japan. Landslides 2020, 17, 641-658. [CrossRef]

33. Gu, X.D.; Liu, X.H. Rock Formations in Sichuan; China University of Geosciences Press: Wuhan, China, 1997.

34. Xu, W.C. Research on Hydrogeological and Environmental Geological Survey Strategy in Sichuan Province. Earth 2015, 10, 229.

35. CGEIS. China Geological Environment Information Site. Bulletin of National Geological Hazards 2004-2016. Available online: http://www.cigem.gov.cn (accessed on 22 February 2017).

36. Trigila, A.; Iadanza, C.; Esposito, C.; Scarascia-Mugnozza, G. Comparison of Logistic Regression and Random Forests techniques for shallow landslide susceptibility assessment in Giampilieri (NE Sicily, Italy). Geomorphology 2015, 249, 119-136. [CrossRef]

37. Li, L.; Liu, R.; Pirasteh, S.; Chen, X.; He, L.; Li, J. A novel genetic algorithm for optimization of conditioning factors in shallow translational landslides and susceptibility mapping. Arab. J. Geosci. 2017, 10, 209. [CrossRef]

38. Reichenbach, P.; Rossi, M.; Malamud, B.D.; Mihir, M.; Guzzetti, F. A review of statistically-based landslide susceptibility models. Earth-Sci. Rev. 2018, 180, 60-91. [CrossRef]

39. Dai, F.C.; Lee, C.F.; Li, J.; Xu, Z.W. Assessment of landslide susceptibility on the natural terrain of Lantau Island, Hong Kong. Environ. Geol. 2001, 40, 381-391. [CrossRef]

40. Wang, Y.; Fang, Z.; Hong, H. Comparison of convolutional neural networks for landslide susceptibility mapping in Yanshan County, China. Sci. Total Environ. 2019, 666, 975-993. [CrossRef]

41. Zhu, A.X.; Miao, Y.; Yang, L.; Bai, S.; Liu, J.; Hong, H. Comparison of the presence-only method and presence-absence method in landslide susceptibility mapping. Catena 2018, 171, 222-233. [CrossRef]

42. Freire, A.P.C.F.; Elkins, M.R.; Ramos, E.M.C.; Moseley, A.M. Use of 95\% confidence intervals in the reporting of between-group differences in randomized controlled trials: Analysis of a representative sample of 200 physical therapy trials. Braz. J. Phys. Ther. 2019, 23, 302-310. [CrossRef]

43. Fu, Q.X. Landslide Spatiotemporal Susceptibility Analysis of Chengdu-Yaan' Section in Sichuan-Tibet Railway. Master's Thesis, Central South University, Changsha, China, 2017.

44. Wang, Y.; Wang, J.; Balakrishnan, S.; Singh, A. Rate optimal estimation and confidence intervals for high-dimensional regression with missing covariates. J. Multivar. Anal. 2019, 174, 104526. [CrossRef]

45. Hespanhol, L.; Vallio, C.S.; Costa, L.M.; Saragiotto, B.T. Understanding and interpreting confidence and credible intervals around effect estimates. Braz. J. Phys. Ther. 2019, 23, 290-301. [CrossRef] [PubMed] 
46. Noce, L.; Gwaza, L.; Mangas-Sanjuan, V.; Garcia-Arieta, A. Comparison of free software platforms for the calculation of the $90 \%$ confidence interval of $\mathrm{f} 2$ similarity factor by bootstrap analysis. Eur. J. Pharm. Sci. 2020, 146, 105259. [CrossRef] [PubMed]

47. Wang, W.D.; Li, J.; Han, Z. Comprehensive assessment of geological hazard safety along railway engineering using a novel method: A case study of the Sichuan-Tibet railway, China. Geomat. Nat. Hazards Risk 2020, 11, 1-21. [CrossRef]

48. Liu, M.; He, Y.; Wang, J.; Lee, H.P.; Liang, Y. Hybrid intelligent algorithm and its application in geological hazard risk assessment. Neurocomputing 2015, 149, 847-853. [CrossRef]

49. Nedumpallile Vasu, N.; Lee, S.-R.; Pradhan, A.M.S.; Kim, Y.-T.; Kang, S.-H.; Lee, D.-H. A new approach to temporal modelling for landslide hazard assessment using an extreme rainfall induced-landslide index. Eng. Geol. 2016, 215, 36-49. [CrossRef]

50. Stancanelli, L.M.; Peres, D.J.; Cancelliere, A.; Foti, E. A combined triggering-propagation modeling approach for the assessment of rainfall induced debris flow susceptibility. J. Hydrol. 2017, 550, 130-143. [CrossRef]

51. Sandric, I.; Ionita, C.; Chitu, Z.; Dardala, M.; Irimia, R.; Furtuna, F.T. Using CUDA to accelerate uncertainty propagation modelling for landslide susceptibility assessment. Environ. Model. Softw. 2019, 115, 176-186. [CrossRef]

52. Gayen, A.; Pourghasemi, H.R.; Saha, S.; Keesstra, S.; Bai, S. Gully erosion susceptibility assessment and management of hazard-prone areas in India using different machine learning algorithms. Sci. Total Environ. 2019, 668, 124-138. [CrossRef]

53. Park, H.J.; Jang, J.Y.; Lee, J.H. Assessment of rainfall-induced landslide susceptibility at the regional scale using a physically based model and fuzzy-based Monte Carlo simulation. Landslides 2019, 16, 695-713. [CrossRef]

54. Segoni, S.; Tofani, V.; Rosi, A.; Catani, F.; Casagli, N. Combination of Rainfall Thresholds and Susceptibility Maps for Dynamic Landslide HazardAssessment at Regional Scale. Front. Earth Sci. 2018, 6, 1-11. [CrossRef]

55. Xia, X.L.; Liang, Q.H. A new depth-averaged model for flow-like landslides over complex terrains with curvatures and steepslopes. Eng. Geol. 2018, 234, 174-191. [CrossRef]

56. Li, L.; Nearing, M.A.; Nichols, M.H.; Polyakov, V.O.; Guertin, D.P.; Cavanaugh, M.L. The effects of DEM interpolation on quantifying soil surface roughness using terrestrial LiDAR. Soil Tillage Res. 2020, 198, 104520. [CrossRef]

57. Shahri, A.A.; Spross, J.; Johansson, F.; Larsson, S. Landslide susceptibility hazard map in southwest Sweden using artificial neural network. Catena 2019, 183, 1-14. [CrossRef]

58. Lin, C.H.; Lin, M.L.; Peng, H.R.; Lin, H.H. Framework for susceptibility analysis of layered rock slopes considering the dimensions of themapping units and geological data resolution at various map scales. Eng. Geol. 2018, 246, 310-325. [CrossRef]

59. Scheltinga, R.T.; Coco, G.; Kleinhans, M.G.; Friedrich, H. Observations of dune interactions from DEMs using through-water Structure from Motion. Geomorphology 2020, 359, 107126. [CrossRef]

60. Tang, X.; Li, J.; Liu, M.; Liu, W.; Hong, H. Flood susceptibility assessment based on a novel random Naïve Bayes method: A comparison between different factor discretization methods. Catena 2020, 190, 104536. [CrossRef]

61. Nian, T.K.; Guo, X.S.; Zheng, D.F.; Xiu, Z.X.; Jiang, Z.B. Susceptibility assessment of regional submarine landslides triggered by seismic actions. Appl. Ocean Res. 2019, 93, 101964. [CrossRef]

(C) 2020 by the authors. Licensee MDPI, Basel, Switzerland. This article is an open access article distributed under the terms and conditions of the Creative Commons Attribution (CC BY) license (http://creativecommons.org/licenses/by/4.0/). 